\title{
ETHICS, CORRUPTION, GOVERNANCE AND EMERGING MARKETS
}

\author{
Valdir de Jesus Lameira \\ E-mail: vlameira@uol.com.br \\ PUC-RJ/ Brasil \\ Hélène Bertrand \\ E-mail: bertrand@iag.puc-rio.br \\ PUC-RJ/ Brasil
}

\begin{abstract}
In this article we seek to substantiate the relation between ethics, corruption, governance and development in emerging markets, especially in Latin America. This is a theorical article where we develop a conceptual model with relations between ethics, corruption and the improve of governance of the countries. We first construct a relation between ethics and corruption and between corruption and governance of the country. For doing this last relation, we consider that the level of the corruption in a country is opposite of the level of governance. Then, we try to provide evidence of the relation between the levels of governance of twenty five emerging nations and their economic performance indicators. The data of the twenty five emerging countries around the world, that we use in the tables, were collected at the World Bank site. We observe the need to improve the ethic all around the countries in Latin America and in many of the emerging countries. We also observe the need to diminish the corruption in some of emerging countries. We conclude that institutions and governments must act speedily and effectively to improve the environment for business in various emerging markets, in order to provide more adequate conditions for world trade growth and satisfy the needs of consumers worldwide.
\end{abstract}

Key-words: ethics, governance, corruption, economic development, emerging markets, organizations.

\section{INTRODUCTION}

Firms engage in commercial transactions in a global macro-environment permeated with very different kinds of relationships, including ethical and unethical practices and outright corrupt ones. In this article we examine the concept of ethics, corrupt practices, which are its most extreme degeneration, and governance mechanisms which aim at controlling and improving business practices.

Faced with this situation, countries and organizations are realizing that they must seek to implement governance practices that enable them to become more efficient at attracting resources. Firms also wish to establish successful partnerships, manage their strategic 
alliances and improve customer perception of their brands, in order to conquer their loyalty and thus increase revenues.

To achieve these objectives, countries must first of all become more efficient at creating the conditions necessary, at both the country and organizational level, to generate a greater volume of business. We are referring to the governance of countries, and how it can improve the economic and financial macro-environment, providing organizations with an infrastructure that gives them a competitive advantage in relation to other organizations in markets that do not share such principles.

Therefore, we decided to choose the relation between governance in emerging markets, the development of these markets and the behavior of organizations, as the central issue to be investigated by our research.

Keegan and Green (2000) point out that global marketing activities take place in a political environment of government institutions, political parties and organizations, through which a country's population and their representatives exercise power. Thus it is understandable that all firms are concerned with the political environment and its risks, the efficiency of the judicial system, the quality of regulation, the possibilities of expropriation and the corruption that may permeate business activities in this society.

To achieve our objective, we developed a conceptual framework, involving ethics, corruption and governance. We then investigated the current state of development of the world's regions, and tried to establish relationships between emerging countries' levels of governance and economic development indicators, in order to infer possible effects and consequences for the organizations that operate in this environment.

Thus, in the second section, we build a theoretical framework in which we set out our concepts of ethics, corruption and governance.

In the third section we develop a research methodology to enable us to relate governance indicators to economic development variables, in order to provide us with information regarding possible links between ethics, governance, corruption and economic development in emerging markets.

In the fourth section we discuss the results of our research, in order to generate knowledge that may be of use to organizations in their actions. In the final section we list the bibliography used for this article. 


\section{THEORETICAL REFERENCES}

Ethics, according to Stone (2005), discusses what is right and what is wrong, just and unjust, and the issue of duties and rights, on a scale that goes from what is morally acceptable and preferable to what is morally prohibited. However, the extent to which the concept permeates life nowadays is much stronger than could have been imagined some time ago. According to Zajdsznadjer (2001), contemporary society has lost important references to assess its posture regarding religion, science and reason, leaving technology and capitalism in need of something to align and balance them.

Zajdsznadjer (2001) suggests that ethics appears in this context as a tool that can be used to achieve a better quality of life, based on the values of veracity, commitment and care.

Thus this concept, which pervades all human activities, has a particularly strong impact on the financial environment due to the risks associated with unethical actions.

According to Stone (2005), ethics is important in international business for three main reasons. Firstly indivíduals need guidelines to enable them to identify ethical and unethical actions, and define paradigms to be achieved. The second is that other agents must be induced to adopt the same standards of conduct, which leads to a questioning of the principles adopted by others to fulfill their self-interest. The third objective is to be able to justify the imposition of laws or political actions against those who have not adhered to established ethical standards.

These reasons demonstrate the importance of defining the limits between ethical and unethical behavior. Moreover, according to Dempsey (2000), the ethics of a community impacts the behavior of all the individuals inside and outside this community, through the daily interactions of the business and commercial operations conducted by these individuals.

In the same way, individual and community ethics interact with individuals incorporating the latter's ethics into their way of acting with other citizens, and being influenced by them in their relations with organizations.

Thus, the author concludes that as society develops better ethical frameworks, these values are incorporated into the ethics of institutions. In this way, the development of better standards of ethical conduct on the part of society, increases the efficiency of organizations due to a reduction in the occurrence of conflicts of interest.

However, Dempsey (2000) highlights an important perspective on the issue of ethics in organizations, which is that individuals are exhorted to be ethical in accordance with the standards of motivation defined by the organization and not according to their own 
consciences. Thus profits become a reference for justifying conducts and serve as a parameter for judgments of the limits between the ethical and unethical.

In our perspective, unethical conduct involves self-serving actions on the part of individuals or organizations aimed at obtaining advantages that flout established rules. This may degrade relations between individuals and organizations and culminate in corrupt conduct.

Thus, we see that corruption is the result of a state of degradation of values, judgments and conducts that, albeit in a simplified form, represents the way a part of society thinks and acts. Therefore the attempt to measure a society's levels of ethical conduct and corruption presupposes the building of a reductionist model that provides only a superficial understanding of such a complex phenomenon.

However, in this article we seek to clarify the relationships between ethical, corrupt and governance actions and their impacts on emerging markets and organizations, and on the latters' day-to-day commercial relations with their customers. To achieve our goal we must obtain a clearer understanding of what is meant by acts of corruption.

Corruption involves corruptors and the corrupt in relations that do not conform to prevailing ethical standards in modern societies. Though it is the corrupted party that nearly always attracts the most condemnation, it is the corruptor that plays the most important role in the relationship because he uses economic, financial a political pressure to obtain an illicit advantage.

In this situation, the logic of profit or financial gain leads us to concentrate all our wrath on the corrupted parties, because their acts provoke losses that can be apprehended more easily by the countless societal actors who have lower levels of economic, financial, political or social power. The actions of corruptors, on the other hand, are harder to visualize and require a greater degree of knowledge to be apprehended by the population. According to Zajdsznadjer (2001), we can therefore understand why some countries and elites limit the access of a large part of their populations to education and culture.

This perspective is confirmed by the information contained in the fourth edition of the United Nations report, "Global Monitoring of Education for All”, that a mere 12 countries concentrate $75 \%$ of the world' illiterate: India, China, Bangladesh, Pakistan, Nigeria, Ethiopia, Indonesia, Egypt, Iran, Morocco, the Democratic Republic of the Congo and Brazil. According to the UN, there is a strong link between adult literacy rates and higher levels of health, income and citizenship. 
Transparency International has created a rudimentary index that measures existing levels of corruption throughout the world, using assessments of government practices made by executives assembled in world events promoted by the World Economic Forum.

Transparency International has discovered that large-scale corruption in public projects is creating serious obstacles to sustainable development throughout the world, and leading to a significant loss of public funds needed for education, health and social programs, in both emerging and developed countries.

Moreover, according to information from this same organization, the loss of resources due to government corruption amount to around US\$ 400 billion a year, worldwide. Other data from research carried out in 2004 , and which is important to gauge the level of societal imbalances throughout the world, show that 106 of the 146 countries in the sample investigated have a corruption index of less than 5 , on a scale of 0 to 10 , where 0 indicates the absence of governance practices, and 10 the highest level of these practices. 60 countries have an index of less than 3 , and 7 less than 2 .

Thus, according to Transparency International, corruption, which was formerly considered to be merely a moral issue, has become a more serious threat because of the costs it imposes on the State's various areas of jurisdiction (social, economic and political). This organization also informs that, despite the biases of the methodology used to calculate the governance index, it is highly correlated with low levels of economic growth and investment, health problems and low levels of education.

Accordingly, reducing the number of cases of corruption, involves adopting legislation to curb illicit persuasion practices throughout the world, and enforcing better rules of corporate governance and compliance codes, to combat corruption in the organizational structure of States.

Thus the methodology developed by Transparency International to measure degrees of corruption, involves assessing the role of the constituted powers of the State and their audit systems, the existence of payments of kickbacks to some classes of civil servants, the weakness of civil institutions, and the distorted relations between the State and the private sector. However as we have already seen, and also according to this institution itself, corruption is merely a symptom of the maladjustment of institutions and society as a whole.

In order to share knowledge which it has accumulated over time, Transparency International lists some measures and strategies that have been adopted by countries all over the world, to mitigate and prevent corruption. 
In this context, one can understand how important it is to choose principles and values than can enable a more favorable environment to be created for the development of relations between individuals and organizations, especially in the business sphere.

Governance practices can make an important contribution to reducing levels of corruption, and are based on four fundamental concepts: the equitable treatment of individuals, transparency of entrepreneurs' and regulators' actions, the responsibility assumed in executing tasks and achieving objectives, and the respect for laws, rules and forms of conduct that are acceptable to society.

Having seen that many suggestions of measures to reduce levels of corruption in business and increase ethical behavior, directly or indirectly, involve concepts related to governance, it is necessary to define the concept of a country's governance more clearly, and ascertain the impacts it can have on both the macro and micro business environments.

According to Kaufmann (2005a), the challenges posed by countries' governance practices and corruption have, in recent decades, been traditionally associated with poorer countries, with richer countries providing the benchmarks. In general, the criteria used to assess governance involve the legal framework and the quality of institutions, especially public ones, and it is not usual to link governance or local security problems to global ones.

Kaufmann (2005a) also shows that governance is an extremely complex variable which includes countless perspectives, and by not defining a specific set of characteristics, one is able to construct various indicators, allowing several different analyzes to be made.

However, Kaufmann, Kraay and Mastruzzi (2003) expanded Kaufmann, Kraay and Zoido-Lobatón's (1999a, 1999b and 2002) definition of the components that should be measured and analyzed in order to construct a country's governance index, and listed the following groups of subjects that should be investigated to construct a country's governance indicator:

A - Voice and accountability - include indicators that measure aspects related to the political process, civil liberties and political rights. In so doing, the authors' intention is to assess to what extent a country's citizens are able to choose their rulers and exercise citizenship.

B - Political stability and absence of violence - this item includes various indicators relating to the possibility that the local government may be destabilized and / or removed from power by unconstitutional or violent acts, or of the occurrence of a civil war or terrorist acts. 
C - Government effectiveness - this group contains a series of replies regarding the quality of public services and bureaucracy, the competence of civil servants, the latters' independence from political pressure and the credibility of their commitment to public service.

D - Regulatory quality - this item includes assessments of the possibility of the occurrence of practices which are contrary to the proper functioning of the market, such as price controls, poor supervision of the banking system or regulatory excess in areas such as foreign trade and financial markets.

E - Rule of Law - this item includes various indicators the related to perceptions of the efficient functioning of the legal system and law enforcement, and they therefore measure perceptions of the incidence of crime, the efficiency and predictability of the judicial system, and the degree to which contracts are enforced.

F - Control of corruption - this group contains indicators that measure perceptions of the level of corruption defined as the exercise of public power for private gain. Two main indicators are used. The first one measures the frequency of additional payments (a bribe or illicit advantage) to receive invoices or celebrate contracts with a clear / evident loss to the public coffers. The second indicator enables an evaluation to be made of the State's capture by, for example, oligarchies, the armed forces, ethnic groups or corrupt politicians.

According to Kaufmann (2005), the State's capture may also be linked to the creation of obstacles to its reform and modernization, which is designed to make it more efficient and thus better adapted to the demands of a dynamic global economy. Moreover the State's degree of transparency and competitiveness forms a dividing line that separates normal lobbying from acts of corruption.

In general, elites capture the State by:

- Purchasing legislators' votes in decision relating to their interests;

- Purchasing decisions emanating from the executive and judicial branches;

- Influencing the regulations of the financial and political systems;

- Illegal financing of election campaigns.

We also understand that it is possible to define the governance of a country in a much broader way, by establishing a parallel with the concepts developed by La Porta, Lopes-deZingales and Schleifer (1998) for the private sector. Thus we could define it as the group of voluntary practices adopted by societies and their representatives, in order to better control political and financial risks (related to the country's administration and possibility of default), 
but which also involve a more equitable treatment of the population's interests. Moreover, they must also involve improving current legislation and society's capacity to enforce it. However this article's purpose is not to develop a methodology for a new questionnaire, as the basis for another country governance index. We made the above comments merely to open up new possibilities for assessing a country's governance practices.

Using the indicator developed by Kaufmann, Kraay and Mastruzzi (2003), and relating it to the wealth indicators of various countries, the authors concluded that there is no general link enabling one to associate good governance practices with rich countries and bad practices with poor ones.

Similarly, they also found that it is not appropriate to assess the quality of a country's governance in terms of its compliance with certain legal standards. Regarding this point, the authors mention that most countries' elites grasp the power to dictate the rules of the game, leading to manifestations of "legal acts of corruption" as opposed to "illegal acts of corruption".

Still with respect to the quality of governance, the author states that it is extremely important to examine the practices of transnational and domestic firms in order to define ethical standards in business. In this context, it seems clear that the private domestic and foreign sectors intertwine in day-to-day commercial operations with the public sector, in which the latter either reproduces or initiates a process permeated by a lack of ethics, transparency or equity, especially in emerging markets.

Thus, using empirical data from the surveys of executive opinion carried at events organized by the World Economic Forum, Kaufmann (2005b) was able to make an initial analysis of these variables on a worldwide basis. He verified, amongst other things, that executives of rich countries perceive a deterioration in the control of corruption involving the judiciary, whereas the perception of in emerging countries is that control in this sphere is improving.

An overview of the figures shows that there are considerable differences between groups of countries or regions. This is especially true when figures from OECD countries are compared with those from regions such as Latin America, or groups of countries like the New Industrializing Countries, as one can see in Kaufmann (2003) and Kaufmann (2005a).

With respect to problems regarding the consequences of bad governance practices on the part of countries, the World Bank's 2005 Equity and Development report, makes it clear that in order to fight poverty, and therefore violence, more efficiently, it is fundamental that societies better operationalize the concept of equity, understood as "equality of opportunity 
for people". In order to do this, it will be necessary to increase the poor's access to health, education, job, capital and land property rights, by providing more equal access to political freedoms and public authorities, and also eliminating stereotypes and improving access to judicial and infrastructure systems.

Thus, we can see that the globalization of business has increased concerns with ethics, corruption and governance practices, and it is important to point out that the globalization process has created a network of links between countries' economic, political, social and cultural facts. Because of this, it is impossible to exclude aspects related to business ethics, governance mechanisms and forms of corruption from the list of issues embraced by the globalization process, just as one cannot deny that there is a strong conceptual relation between these variables and the development of organizations and therefore countries.

To improve the business environment, it is absolutely essential to improve countries' governance practices. Huther and Shah (2005) have listed various examples of empirical evidence of anti-corruption programs throughout the world, including references to academic studies, and we include a synthesis of their findings below:

\begin{tabular}{|c|c|}
\hline Program & Empirical and academic evidence \\
\hline Anti-corruption agencies & $\begin{array}{l}\text { This kind of institution has been successful in Chile, Hong } \\
\text { Kong, New Zealand, Australia and Singapore according to } \\
\text { Segal (1999) and the World Bank (2000). However, } \\
\text { according to Kaufmann (1997), developed countries do } \\
\text { not regard these agencies as effective instruments in } \\
\text { curbing endemic corrupt practices. }\end{array}$ \\
\hline Public opinion polls & $\begin{array}{l}\text { Increase awareness of problems related to corruption, } \\
\text { epecially in countries with endemic problems. }\end{array}$ \\
\hline $\begin{array}{l}\text { Raising public sector } \\
\text { compensation }\end{array}$ & $\begin{array}{l}\text { Treisman (1999) and Swamy et al. (1999) could not find } \\
\text { any relation between increases in compensation and a } \\
\text { decline in corruption. However, impacts were verified on } \\
\text { small economically insignificant problems. }\end{array}$ \\
\hline $\begin{array}{l}\text { Reduction of the size of } \\
\text { the public sector }\end{array}$ & $\begin{array}{l}\text { There are studies such as Tanzi and Davoodi's (1998) that } \\
\text { show that the smaller the public sector the lower the level } \\
\text { of corruption. However privatizations in some countries } \\
\text { (Russia, for example) led to an increase in corruption. }\end{array}$ \\
\hline
\end{tabular}


ETHICS, CORRUPTION, GOVERNANCE AND EMERGING MARKETS

\begin{tabular}{|c|c|}
\hline & $\begin{array}{l}\text { Efficient government control systems are considered to be } \\
\text { the main way of reducing corruption. }\end{array}$ \\
\hline $\begin{array}{l}\text { Fiscal and financial } \\
\text { responsibility }\end{array}$ & $\begin{array}{l}\text { Gurgur and Shah (2000) were unable to verify a significant } \\
\text { relation. }\end{array}$ \\
\hline Independence of the media & $\begin{array}{l}\text { Brunetti and Weder (1998) verified that press freedom is } \\
\text { negatively related to the level of corruption }\end{array}$ \\
\hline $\begin{array}{l}\text { Independence of the } \\
\text { judiciary }\end{array}$ & $\begin{array}{l}\text { Gurgur and Shah (2000) verified a statistically significant } \\
\text { relation between a greater independence of the judiciary } \\
\text { and a decline in levels of corruption. }\end{array}$ \\
\hline Participation of citizens & $\begin{array}{l}\text { Gurgur and Shah (2000) found a statistically significant } \\
\text { relation between an increase in citizens' participation and a } \\
\text { decline in levels of corruption. }\end{array}$ \\
\hline Decentralization of power & $\begin{array}{l}\text { Gurgur and Shah (2000) also verified a statistically } \\
\text { significant relation between a greater decentralization of } \\
\text { power and a decline in corruption levels. }\end{array}$ \\
\hline $\begin{array}{l}\text { Type of bureaucratic } \\
\text { culture }\end{array}$ & $\begin{array}{l}\text { Gurgur and Shah (2000) also found that there is a } \\
\text { statistically significant relation between the type of } \\
\text { command and existing controls and the level of corruption. } \\
\text { Thus a greater decentralization and more efficient controls } \\
\text { tend to reduce levels of corruption. }\end{array}$ \\
\hline
\end{tabular}

Source: Huther and Shah. Anti-corruption policies and programs: a framework for evaluation, (October, 2005).

Wei (2005) verifies that a country's level of governance can be gauged by its fulfillment of each of the above requirements. However, he concludes that the existing environment is a critical factor in determining success. Thus where corruption is not endemic, the creation of anti-corruption programs leads to an improvement in the situation, unlike in those countries where corruption has attained very high levels, compromising the whole structure of business.

Thus Wei (2005) found that anti-corruption programs were most successful where flaws in control and governance were negligible, thus providing few opportunities for obtaining advantages, and where they were able to put a vast network of sanctions in place. 
In order to achieve a better understanding of our argument so far, we have built a conceptual model in which we relate ethics, corruption and governance to a society's level of economic development. Its broad conception was intentional, in order to allow future research to widen and deepen possible relations, by carrying out an empirical investigation of the phenomenon using more complex models.

Conceptual Model:
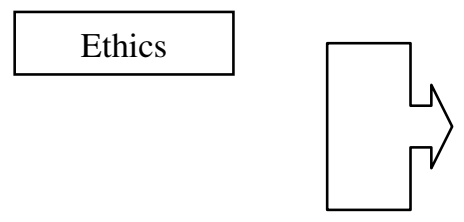

Governance

Corruption

Source: The authors.

\section{RESEARCH METHODOLOGY AND ANALYSIS OF THE DATA}

Our research, which is of an exploratory nature and follows a neo-positivist epistemological approach, seeks to understand the impacts of corruption on the development of a sample of emerging markets in order to be able to develop some generalizations regarding their situation.

We obtained secondary data from the World Bank and Transparency International websites to provide a basis for our empirical investigations.

To construct the empirical database shown in our article, we selected the economic, financial and social data from the World Bank website that we believed would constitute good indicators for the development of nations.

At the website we found economic, financial and social data for the 2000-2004 period. However there was no data for most countries in 2004, and 2003 data was lacking for some of the countries in our sample. An example is the complete absence of data for East European countries during the period analyzed.

To construct this sample, we included all those emerging counties with large domestic products that possessed indicators for all the variables selected by the research to represent countries' economic development. 
ETHICS, CORRUPTION, GOVERNANCE AND EMERGING MARKETS

We included empirical data relating to the governance levels and economic variables of 25 emerging countries, in order to assure the statistical significance of the results. As we were interested in a conceptual discussion of the theme at issue, we did not use more sophisticated statistical methods, merely using the medians and standard deviations of the indicators researched, and calculating their degree of correlation with countries' governance indicators.

Lastly, it should be mentioned that we tried to include most South America countries in order to awaken people to the need to adopt better governance practices in this region.

We believe that the following variables represent development conditions quite adequately: Direct Investment (MEDDI), GDP size (MEDGDP), GDP Growth (MEDGROW), Foreign Trade (MEDFT), Gross Fixed Investment (MEDGFI) and Per Capita Income (MEDPCI). We then correlated these economic variables with the governance index (MEDGI) during the 2000-2002 period, using the arithmetic average of the values collected as the value of these indicators' variables.

The following questions, the replies to which are measured on a Likert scale, help to prepare the country governance index, and can be posed to any person, in any part of the world, as long as he or she has the profile suggested by Transparency International. These questions, made during the data collection period, 2000 to 2002, are listed below:

1 - How common is it for additional payments to be made, and how problematic is corruption for the development of business?

2 - How deeply do the problems of corruption within the State go?

3 -How can one define wrong or inappropriate use of one's public function to obtain private gain?

4 - How widespread are corrupt practices in government, and what anti-corruption measures have been taken, as perceived by the public and published in the media?;

5 - How common is the payment of kickbacks to do business, what is their relative cost and how often are kickbacks derived from public-sector contracts paid to friends or relatives in neighboring countries?

6 - Do the payment of kickbacks and corruption exist in the economy?

7 - How widespread are corrupt practices in the economy?

8 - What is the level of corruption and payment of kickbacks to government employees?

9 - What is the perceived level of corruption in the country in which you operate? In your country of origin? 
10 - How often are kickbacks paid to politicians, federal civil servants or judges? What is the degree of correlation between obstacles to business and the payment of these kickbacks?

11 - How likely is one to find corruption stretching from the lowest echelons of bureaucracy to the highest political level?

12 - What is the incidence of undocumented payments connected with government functions?

In table I, we show the assessments of governance levels (MEDGI) verified in several countries, in accordance with the methodology presented by Transparency International. We also relate the level of governance (MEDGI) to values for Direct Investment (MEDDI), size of GDP (MEDGDP), GDP Growth (MEDGROW), Foreign Trade (MEDFT), Gross Fixed Investment (MEDGFI) and Income per Capita (MEDIC) during the 2000-2002 period.

It is important to emphasize that the higher a country's governance indicator the better its governance, which means that there is less corruption in that society.

\title{
"TAKE TABLE I"
}

In order to obtain a broader understanding of the phenomenon of economic development we now list some variables such as electric power consumption per inhabitant, the number of fixed and mobile phones per 1000 inhabitants, the number of computers per 1000 inhabitants, dollar per capita income and the rate of GDP growth of some of the world's economic regions.

Thus, by including data taken from the World Bank's website, we are able to obtain a better understanding of some important development indicators that are not linked merely to the financial and commercial performance of countries or regions, but also to perceived quality of life in different places of the world.

\author{
"TAKE TABLE II" \\ “TAKE TABLE III" \\ “TAKE TABLE IV” \\ "TAKE TABLE V"
}




\section{"TAKE TABLE VI"}

Thus we verify that the consumption of electric power, the number of fixed and mobile phones, and computers per 1000 inhabitants, are closely correlated with a region's relative economic importance, and this is also true of per capita income indicators..

Accordingly, OECD countries, followed by those in the Euro region, are better equipped for economic development than Latin American, Middles Eastern, North African and medium-sized countries. Lastly, one verifies that the indicators of the most indebted and least developed countries are appalling.

In spite of this, it was the least developed, most indebted and medium-sized countries that grew the fastest during the period analyzed. To our surprise Latin American and the Caribbean countries had the world's lowest rates of growth.

With the exception of Chile, the other South American countries in the sample of the economically most important emerging countries, presented results that varied between 2.37 and 4.17, denoting a low level of governance (MEDCGI).

Australia and Chile stood out in terms of governance (or corruption) indices, and were for above the emerging country sample's median of 4.05 and standard deviation of 1.60.

We verified that 20 of the 22 countries, or $91 \%$, are situated in the interval between two standard deviations above and below the median which is the $(0.84 ; 7.26)$ interval where $95 \%$ should be situated. In practice, this is true of $91 \%$ of cases.

Of the total of 25 countries, 18 or $72 \%$ are situated between the interval of a standard deviation above or below the median $(2.45 ; 5.85)$, which concentrates $68 \%$ of the distribution's values.

The results in table 1 show that there is a negative correlation between the index of governance and the volume of Direct Investments (MEDDI), Size of GDP (MEDGDP) and the Economic Growth rate (MEDGROW).

For example, many countries with low governance indicators receive a volume of funds far superior to the average of US\$ 12 billion a year. Australia and Hungary have good governance indicators and receive a level of foreign investments above the average. The others, such as China have mediocre or poor indicators but receive large volumes of foreign investment.

As for the relation between the governance index and the other economic development indicators in table 2 , the results show a positive correlation between a higher level of governance and the volume of Foreign Trade (MEDFT), Gross Fixed Investment (MEDGFI), 
which can be considered a proxy for a country's capacity to generate investment - and Income per Capita (MEDIC).

\section{DISCUSSION OF THE THEME}

Our main objective was to investigate whether countries with better governance practices have higher economic growth, using GDP growth as an indicator, or receive more foreign investment, measured by the volume of direct investment. We were unable to confirm this hypothesis for the countries in our sample from the figures covering the 2000-2002 period. Nonetheless, we believe that other studies should seek to establish this relation by increasing the time period and the number of countries.

However, we also used other indicators such as a country's volume of foreign trade, level of gross fixed investment and income per capita, and verified that countries with sounder governance practices have better indicators than those with poor levels of governance. This indicates that governance is associated with parameters that in the long term, will impact economic growth, per capita income, countries levels of savings (represented by gross fixed investment) and volume of foreign trade.

On a conceptual plane, we verified that ethics is extremely important as a driving factor behind business and economic development, and embraces a broader concept called governance, which is related to the way countries manage to control unethical actions such as those involving corruption.

In a broader sense, countries with better governance indicators and thus lower corruption indicators provide more appropriate conditions for economic development. The best examples are Australia and Chile. Kaufmann and Kraay (2002) prove that there is strong and positive relation between improvements in levels of governance and increases in countries' per capita income.

However, we verify that the countries which receive the largest volume of foreign investment are not those with the best governance indictors. This group of countries includes Chine, India, Russia and Brazil. Albuquerque, Loayza and Servén (2005) investigated the factors which affect foreign investment flows, and concluded that the integration of capital markets and economic liberalization are the global factors that have most contributed to this. However, they also point out that foreign investors' decisions are strongly influenced by local 
factors such as productivity, degree of trade liberalization, reduction of government spending and economic stability.

Thus we may conclude from the results shown in table 1 , that even though there is no direct correlation between a country's level of governance and the amount of foreign investment received, it certainly has a positive impact, given that greater economic stability and government fiscal equilibrium improve governance and enable firms to plan better and increase their profitability.

We also proved that there is a negative correlation between a country's level of governance and the size of its GDP and rate of growth. This means that countries with large GDPs and high growth rates may have more corruption simply because they have a greater volume of transactions, and because growth may conceal actions of corruption and economic efficiency, leading to a decline in the level of perception of internal problems.

However we were also able to show that higher levels of governance are positively related to the volume of foreign trade, government savings and income per capita. Thus we may conclude that better levels of governance are directly related to large volumes of foreign business, a greater investment capacity on the part of the state, and consequently more optimistic expectations as to the future of the economy. Lastly, higher levels of governance are associated with larger per capita incomes, and therefore more equitable conditions and a greater economic and social growth potential.

Thus we verified that in order to improve the business environment it is necessary to improve governance, reduce corruption and establish ethics firmly in contemporary mankind's transactions and mindset.

Therefore in the current context, it is fundamental that equitable and transparent conditions prevail, imbued with a respect for laws and rules, and in which business is conducted by responsible and ethical individuals.

Only in this way will organizations prosper in the environment of sustainable peace and possible world equilibrium which are so important for the planet's citizens and sustainable growth. Similarly, Fort and Schipani (2005) affirm that transnational and multinational firms can contribute to sustainable peace by changing the way they exercise power. This means improving their governance practices, and especially being more equitable, so as to become agents in the quest for a more democratic society in the places where they operate.

Though, according to Moshirian (2003), one may easily observe that national and international institutions all over the world have been finding it increasingly difficult to 
contain an escalation of insecurity and threats to peace, and promote the kind of economic growth that respects global human needs.

Following Moshirian, Klapinsky, Morris and Readman (2002) who analyzed the South Africa real-estate market to discover elements that could be applied to other product markets, concluded that is a growing world disorder caused by market imbalances, the inappropriate actions of agents of developed countries, and by the inability of some emerging economies to improve their efficiency.

In our opinion, there is a quasi consensus that the structures that have not accompanied the change in the global business environment will have to be reformulated. However, it is not so much new structures that are needed, for they are merely instruments, as fresh forms of thinking and acting, fresh values and a complete understanding of human needs.

Fundamentally what is needed is not just to understand today's world (a rational process), or understand problems (put oneself in the other's place and feel), but a kind of "understanding-acting" that leads to the creation of a new way of perceiving and living. Thus it is vital to recover a sense of ethics, and that the acts of states, organizations and individuals be in accordance with the best possible conscious governance practices.

There is a group of global needs (ethics and governance) that corporations and institutions must meet in order to maximize the global customer's satisfaction. To achieve this they must use global marketing to establish a link between their business and institutional activities and the global citizen.

To conclude, we believe that other researchers can further investigate the conceptual link between these variables, by including other values in the conceptual analysis, in order to build a better theoretical framework, which can be used to explain the relation between best country governance practices and economic development.

Furthermore, we should try to find other performance and governance indicators, in order to increase our understanding of the phenomena that have been investigated in this article in an exploratory fashion. Another suggestion for future studies would be to insert one or more corporate governance indicators in the countries of a future sample, in order to analyze their relation with economic development. 


\section{BIBLIOGRAPHY}

Albuquerque, Rui; Loaya, Norman; Servén, Luiz. World market integration through the lens of foreign direct investors. Journal of International Economics, 66, (2005), p. 267-295.

Brunetti, A.; Weder B.. A free press is bad news for corruption. Wirtschaftswissenschaftliches Zentrum der Universitat Basel Discussion Paper, nº 9809, (1998).

Center for Institutional Reform and the Informal Sector (IRIS). Corruption: the enemy of progress. An issue paper presented at the partners in transition European and Eurásia regional conference, Sofia, Bulgaria, September, 2001, available at www.iris.org, (November, 2005).

Dempsey, Michael J. Ethical finance: an agenda for consolidation or radical change. Critical perspectives on accounting, v. 11, (2000), pp. 538-548.

Fort, Timothy L.; Schipani, Cindy A.. Adapting corporate governance for sustainable peace. Vanderbuilt Journal of Transnational Law, (2005).

Gomes, Jonas; Braga, Gilberto. Governança e governabilidade. Valor Econômico newspaper, number 1331, available at : www.valor.com.br/veconomico/?show=imprimir7id=3229383, (August, 2005).

Hellman, Joel S.; Jones, Geraint; Kaufmann, Daniel; Schankerman, Mark. Measuring governance, corruption, and state capture. How firms and bureaucrats shape the business environment in transition economies, (2000). Article available at www.worldbank.org, (November, 2005).

Huther, Jeff; Shah, Anwar. Anti-corruption policies and programs: a framework for evaluation, (2005). Available at www.ssrn.com, (October, 2005).

Huther, J.; Shah, A. A simple measure of good governance and its application to the debate on the appropriate level of fiscal descentralization. World Bank working paper, series $\mathrm{n}^{\circ} 1894$, Washinmgton D.C., (1998). 
Kaplinsky, Raphael; Morris, Mike; Readman, Jeff. The globalization of products markets and immisering growth: lessons from South African furniture industry. World development, v. 30 (7), (2002), p. 1159-1177.

Kaufmann, D. Listening to shareholders' views about corruption in their countries. Harvard Institute of International Development, (1997).

Kaufmann, D. Rethinking governance: empirical lessons challenge orthodoxy, (2003). Article available at www.worldbank.org, (novembro, 2005).

Kaufmann, D. Corruption, governance and security: challenges for the rich countries and the world, (2005a). Available at www.worldbank.org/wbi/governance/eos4, (November, 2005).

Kaufmann, D. Corruption: the enemy of progress. Center for institutional reform and informal sector, (2005b). Issues paper for the partners in transition - II conference, World Bank, (2005).

Kaufmann, D.; Kraay, A. Growth without governance, (2002). Article available at www.worldbank.org, November, 2005).

Kaufmann, D. ; Kraay, A.; Zoido-Lobaton, P. Aggregating governance indicators. World Bank Policy Research Department, working paper series nº 2195, Washington D.C., (1999a).

Kaufmann, D. ; Kraay, A.; Zoido-Lobaton, P. Governance matters. World Bank Policy Research Department, working paper series nº 2196, Washington D.C., (1999b).

Kaufmann, D. ; Kraay, A.; Zoido-Lobaton, P. Governance matters II - updated indicators for 2000/01. World Bank Policy Research Department, working paper series $\mathrm{n}^{\mathbf{o}}$ 2772, Washington D.C., (2002).

Kaufmann, D.; Kraay, A., Mastruzzi, M. Governance matters III: governance indicators for 1996-2002, (2003). Article available at www.worldbank.org, (November, 2005).

Keegan, Warren J; Green, Mark C. Princípios de marketing global. São Paulo, Editora Saraiva, $2^{\mathrm{a}}$ edição, (2000), p. 476. 
La Porta, R.; Lopez-de-Silanes, F.; Shleifer, A. Law \& finance. Journal of Political Economy, v. 106, (1998), p. 1113-1155.

Moshirian, Fariborz. Globalkization and financial market integration. Journal of multinational financial management, v. 13, (2003), p. 289-302.

United Nations (UN). Monitoring education for all global report, 4th edition, available at www.onu.org, (November, 2005).

Segal, P. Dealing with devil: the hell of corruption. Impact, International Finance Corporation, (Spring, 1999).

Shah, A. Governing for results in a globalized and localized world. Mahbub ul Haq lecture at the Pakistan society for development economics, Islamabad, Pakistan, (December, 1999).

Stone, Christopher D. Ethics in International Environmental Law, available at www.ssrn.com/abstract=705263, (novembro, 2005).

Swamy, A.; Kanck, Y. Lee, Azfar, O. Gender and corruption. Iris center, University of Maryland, (July, 1999).

Tanzi, V.; Davoodi, H. Roads to nowhere: how corruption in public investment hurts growth. In: New perspectives on combating corruption, Transparency International and the World Bank, (1998).

Wei, Shang-Jin. Natural openness and good governance. Harvard University. Brookings, World Bank, (October, 2005).

World Bank Development Report (1997). The World Bank, Washington D.C., available at www.worldbank.org, (novembro, 2005).

World Bank. Reforming public institutions and strengthening governance (2000). A World Bank Strategy, November, available at www.worldbank.org, (November, 2005). 
World Bank. Eqüidade e desenvolvimento (setembro, 2005), available at www.worldbank.org, (November, 2005).

Zajdsznadjer, Luciano. Ser ético no Brasil. Rio de Janeiro, Editora Forense - Gryphus, (2001), p. 184. 
Table I - Level of governance values of the 25 main emerging countries in declining order and their correlation with Average Direct Investment, Size of GDP, Economic Growth,

Foreign Trade, Gross Fixed Investment and Per Capita Income

(US\$ billion, US\$ trillion, average \% during the period, US\$ billion, US\$ billion and US\$ thous. dollars/year)

\begin{tabular}{|c|c|c|c|c|c|c|c|}
\hline Countries/Variables & MEDCGI & MEDDI & MEDGDP & MEDGROW & MEDFT & MEDGFI & MEDIC \\
\hline Australia & 8,47 & 25,1200 & 0,3889 & 0,5488 & 34,30 & 23,05 & 19,85 \\
Chile & 7,47 & 3,6500 & 0,0670 & $-1,6951$ & 52,26 & 21,71 & 4,56 \\
Portugal & 6,33 & 4,8200 & 0,1125 & 2,2246 & 57,76 & 27,25 & 10,70 \\
Taiwan & 5,67 & 5,6000 & 0,2935 & 0,4238 & 23,61 & 23,61 & 2,00 \\
Hungary & 5,13 & 23,8400 & 0,0543 & 11,6268 & 121,31 & 27,46 & 4,78 \\
Malaysia & 4,90 & 4,1800 & 0,0909 & 6,4751 & 188,46 & 25,00 & 3,45 \\
South Africa & 4,87 & 8,1000 & 0,1145 & $-7,1068$ & 50,81 & 15,33 & 2,75 \\
Greece & 4,43 & 10,6600 & 0,1206 & 3,7644 & 34,85 & 23,97 & 11,18 \\
Peru & 4,17 & 1,3700 & 0,0547 & 3,0930 & 26,91 & 19,23 & 2,01 \\
Poland & 4,07 & 6,2100 & 0,1743 & 6,9076 & 48,37 & 21,43 & 4,55 \\
Brazil & 3,97 & 23,9400 & 0,5168 & $-15,4495$ & 21,90 & 20,90 & 3,20 \\
Bulgaria & 3,80 & 9,0600 & 0,0137 & 7,9872 & 89,67 & 19,59 & 1,69 \\
Colombia & 3,53 & 2,4200 & 0,0815 & $-1,5386$ & 30,25 & 14,71 & 1,92 \\
Mexico & 3,53 & 19,4000 & 0,6098 & 10,1678 & 55,28 & 21,88 & 5,54 \\
Turkey & 3,53 & 7,8200 & 0,1771 & 1,9483 & 46,34 & 20,87 & 2,64 \\
China & 3,37 & 43,9800 & 1,1683 & 8,4977 & 45,36 & 38,41 & 0,90 \\
Egypt & 3,37 & 4,2700 & 0,0957 & 0,5540 & 18,39 & 17,37 & 1,50 \\
Argentina & 3,27 & 14,3300 & 0,2185 & $-22,3809$ & 23,19 & 14,11 & 6,37 \\
Phillipines & 2,77 & 1,3800 & 0,0747 & 0,9474 & 96,50 & 20,37 & 1,03 \\
Romania & 2,77 & 11,1300 & 0,0404 & 9,3290 & 66,56 & 21,72 & 1,78 \\
India & 2,73 & 33,2100 & 0,4815 & 4,6576 & 20,29 & 22,60 & 0,46 \\
Venezuela & 2,67 & 5,4000 & 0,1133 & $-1,3896$ & 37,89 & 16,92 & 4,37 \\
Russia & 2,37 & 28,8100 & 0,3025 & 21,7311 & 52,86 & 20,68 & 1,88 \\
Equador & 2,37 & 1,1100 & 0,0186 & 12,9995 & 49,73 & 24,50 & 1,40 \\
Indonesia & 1,83 & 0,7700 & 0,1572 & 7,4224 & 58,65 & 16,40 & 0,66 \\
& & & & & & & \\
\hline Correlation between CGI and each & 1,0000 & $-0,0015$ & $-0,0428$ & $-0,2073$ & 0,0687 & 0,2283 & 0,6992 \\
\hline
\end{tabular}

Source: The authors 
Table II - Electric power consumption (Kwh per inhabitant)

\begin{tabular}{|c|c|c|c|c|}
\hline Electric power consumption (kwh per capita) & 2000 & 2001 & 2002 & MED \\
\hline High income: OECD & $8.683,05$ & $8.663,80$ & $8.769,28$ & 8705 \\
\hline European Monetary Union & 5.749 & 5.901 & 5.912 & 5854 \\
\hline World & 2.174 & 2.183 & 2.225 & 2194 \\
\hline Latin America \& Caribbean & 1.532 & 1.492 & 1.506 & 1510 \\
\hline Middle income & 1.330 & 1.367 & 1.422 & 1373 \\
\hline Middle East \& North Africa & 1.302 & 1.358 & 1.412 & 1357 \\
\hline Heavily indebted poor countries (HIPC) & 111 & 126 & 134 & 123 \\
\hline Least developed countries: UN classification & 77 & 90 & 99 & 89 \\
\hline
\end{tabular}

Source: www.worldbank.org; November, 2005.

Table III - Number of fixed and mobile phones (Units per 1.000 inhabitants)

\begin{tabular}{|c|c|c|c|c|}
\hline Fixed line and mobile phone subscribers & 2000 & 2001 & 2002 & MED \\
\hline European Monetary Union & 1148,00 & 1272,00 & 1334,00 & 1251 \\
\hline High income: OECD & 1116,00 & 1200,00 & 1240,00 & 1185 \\
\hline World & 284,00 & 326,00 & 363,00 & 324 \\
\hline Latin America \& Caribbean & 267,00 & 322,00 & 358,00 & 316 \\
\hline Middle income & 204,00 & 263,00 & 323,00 & 263 \\
\hline Middle East \& North Africa & 119,00 & 152,00 & 180,00 & 150 \\
\hline Heavily indebted poor countries (HIPC) & 13,00 & 18,00 & 25,00 & 19 \\
\hline Least developed countries: UN classification & 8,00 & 12,00 & 17,00 & 12 \\
\hline
\end{tabular}

Source: www.worldbank.org; November, 2005.

Table IV - Number of computers (Units per 1.000 inhabitants)

\begin{tabular}{|c|c|c|c|c|}
\hline Personal computers (per 1,000 people) & 2000 & 2001 & 2002 & MED \\
\hline High income: OECD & 396 & 438 & 473 & 436 \\
\hline European Monetary Union & 257 & 285 & 317 & 286 \\
\hline World & 80 & 89 & 101 & 90 \\
\hline Latin America \& Caribbean & 49 & 59 & 67 & 58 \\
\hline Middle income & 30 & 35 & 43 & 36 \\
\hline Middle East \& North Africa & 29 & 33 & 38 & 33 \\
\hline Heavily indebted poor countries (HIPC) & 4 & 4 & 5 & 5 \\
\hline Least developed countries: UN classification & 3 & 3 & 4 & 3 \\
\hline
\end{tabular}

Source: www.worldbank.org; November, 2005.

Table V - Income per Capita (US\$ dollars)

\begin{tabular}{|c|c|c|c|c|}
\hline GNI per capita, Atlas method (current US\$) & 2000 & 2001 & 2002 & MED \\
\hline High income: OECD & 27520 & 27390 & 27220 & 27377 \\
\hline European Monetary Union & 21760 & 20790 & 20320 & 20957 \\
\hline World & 5220 & 5180 & 5130 & 5177 \\
\hline Latin America \& Caribbean & 3710 & 3570 & 3320 & 3533 \\
\hline Middle East \& North Africa & 2130 & 2200 & 2210 & 2180 \\
\hline Middle income & 1750 & 1750 & 1770 & 1757 \\
\hline Least developed countries: UN classification & 280 & 280 & 290 & 283 \\
\hline Heavily indebted poor countries (HIPC) & 280 & 280 & 280 & 280 \\
\hline
\end{tabular}

Fonte: www.worldbank.org; novembro, 2005. 
Table VI - Growth of Gross Domestic Product (\% growth between years)

\begin{tabular}{|c|c|c|c|c|}
\hline GDP growth (annual \%) & 2000 & 2001 & 2002 & MED \\
\hline Least developed countries: UN classification & 4,43 & 4,93 & 4,94 & 4,77 \\
\hline Heavily indebted poor countries (HIPC) & 3,27 & 4,64 & 3,33 & 3,75 \\
\hline Middle income & 5,40 & 2,55 & 3,13 & 3,69 \\
\hline Middle East \& North Africa & 4,14 & 2,67 & 2,69 & 3,17 \\
\hline World & 4,00 & 1,37 & 1,84 & 2,40 \\
\hline High income: OECD & 3,59 & 1,08 & 1,47 & 2,05 \\
\hline European Monetary Union & 3,51 & 1,64 & 0,89 & 2,01 \\
\hline Latin America \& Caribbean & 3,91 & 0,19 & $-0,88$ & 1,07 \\
\hline
\end{tabular}

Source: www.worldbank.org; November, 2005. 